Charles Stewart

Department of Anthropology

UCL

c.stewart@ucl.ac.uk

\title{
Historicity and Anthropology
}

\begin{abstract}
Historicity has emerged within anthropology to refer to cultural perceptions of the past. It calls attention to the techniques such as rituals that people use to learn about the past, the principles that guide them, and the performances and genres in which information about the past can be presented. The concept is in essential tension with the meaning of the term as "factuality" within the discipline of history and in wider society. Anthropologists also sometimes compose histories within this Western paradigm, but historicity in anthropology orientates a different objective, namely to discover the ways (beyond Western historicism) in which people, whether within or outside the West, construe and represent the past. Historicity, which is grounded in a notion of temporality, offers a framework for approaching time as nonlinear and may thus be suited to studying other histories without fundamentally measuring how well they conform to Western history.
\end{abstract}

Keywords history, temporality, coevalness, chronotope, historical consciousness

\section{INTRODUCTION}

The term "historicity" has filtered into anthropological terminology over the past decades because of the need for a concept that captures the fundamental relationality of knowledge of the past. It takes its place next to other phenomenological terms such as "materiality," "sociality," and "environmentality," which point beyond a dualistic view that might assume 
an a priori separation of, respectively, persons from things, individuals from society, and people from environment. These various pairs are to be comprehended, instead, as being in emergent and mutually constitutive relationship. Historicity, or historicality (variant translations of the German Geschichtlichkeit), fit linguistically and theoretically with these terms ending in "-ality." The long development of the historicity concept in philosophy (Ricoeur 2004, p. 370), notably in Heidegger (1996), anticipates the current interest in the reciprocal formation of subjects and objects and the relationship of being to time.

The historian, or any other historical subject, constitutes history through thought, and possibly research and writing, but at the same time this historian is also constituted by historical events in the course of life and through living within frameworks generated in the deeper past. History thus takes shape in a hermeneutic circle consistent with Gadamer's (1994) idea of "historically effected consciousness" (p. 300): The knowing subject does not stand apart from the object but is already a part of it. Wentzer (2014) provides an example of this historicity in his reflections on his personal understanding of his father's statement: "I have seen Königsberg burning." This phrase from his father's account of fleeing from East Prussia in the final months of World War II changed meaning for him from first hearing it as a child to when he became a professional philosopher for whom the city of Königsberg symbolized Kant and Enlightenment reason. The factuality of the past (Königsberg did suffer massive fires in 1944), mediated by his father's narrative, merged into Wentzer's life and his changing reflections not just on the meaning of the story, but on its ethical implications for his life. Wentzer (2014) explores this predicament as a matter of "historical experience" or "the experience of one's own historicity" (p. 43). Historicity asks what is the relationship to the past that individuals establish, given their present position (and intimations of the future), and the models available to them (Hirsch \& Stewart 2005a, Ballard 2014, Hartog 2015). Historicity, like history, wells up in the space between experience and expectation as an enduring feature of the human condition (Koselleck 2004).

The absorption of these "anthropological givens" (Koselleck 2004, p. 259) into disciplinary anthropological thought has been uneven because $(a)$ the original formulations of historicity are pitched at a philosophical level that requires adaptation to anthropological research, and these adaptations have not been coordinated; and $(b)$ the constant presence of competing usages of the term historicity has caused confusion. This article analyzes this 
uncertainty over what historicity might mean and examines how it has been and can be adapted and what theoretical service it might perform for anthropology.

\section{THE DEVELOPMENT OF HISTORICITY IN ANTHROPOLOGY}

I begin with the relatively straightforward matter of semantics and usage. Beyond the philosophical meaning of historicity considered above, the term historicity previously existed and continues to exist in ordinary usage to refer to "the verifiable past" or “factuality." Both the Oxford English Dictionary and Webster's Dictionary give these definitions as the term's only meanings. "Historicity" is first attested in the latter part of the nineteenth century when it emerged as an auxiliary to "historicism"- the goal of the newly emerged discipline of history, namely to provide historicity or to historicize according to rigorous standards of evidence and argument (Iggers 1995, p. 143). The idea of historicity appeared (and still appears), for example, in debates over the stories in the Bible, especially the figure of Jesus. Could the Gospel accounts of his life be verified? In short, do they have historicity? In this everyday sense, historicity describes the endeavor to separate fact from fiction. Western education offers a historicist approach to history that is continuous with science in its insistence on objective evidence and rational inference. Historicity is thus not just an isolated term, but part of a post-Enlightenment thought complex.

The predicament of anthropology is that, as a post-Enlightenment discipline, it belongs to this complex while studying societies that hold different ideas about time (Gell 1992, Munn 1992) and events (Munn 1990, Sahlins 1991, Strathern 2013). The first danger is that anthropologists could gloss over other societies' subtle and oblique modes of relating to the past, assuming that ideas such as chronology, temporal progression, and pastness must be human universals. Second, in providing their own proficient historical accounts of other societies, anthropologists might marginalize or altogether neglect the architecture of local thinking about the past. And finally, endeavoring to give voice to the marginalized and powerless, anthropologists could highlight the political content of counterhistories and neglect the particular principles and practices on which they depend. Indeed, those nonhistoricist ways of relating to the past could be political liabilities, as can be seen in Clifford's (1988) account of how an American court found a Native American group's 
claims about their relationship to the past unconvincing. When the Mashpee tribal chief loosened his tie on the witness stand and withdrew two strings of beads from inside his shirt - one a gift from his father, the other of turquoise from the Southwest - those in the courtroom were surprised and somewhat embarrassed (p. 283). This evidence of spiritual connection to a people and a history could not be convincing within the canons of American historicity that insist on tangible documentary sources.

Since the demise of functionalism, history and anthropology have been combined in many different formulations, beginning with the humanist view of Evans-Pritchard (1961), which contended that these two disciplines shared a common methodology, namely that of understanding others' views of the world whether separated in space or in time; Ortner's (1984) consideration of culture as always changing through the force of human agency and thus a crucible of historical process; and the endeavor to historicize indigenous peoples such as the Native American Mashpee so that they could represent themselves in land claims cases, which spawned the field of ethnohistory (Krech 1991, Harkin 2010). In much of this literature, anthropologists have supplied histories according to the conventions and interrogatives of Western historiography. The recognition that other societies might have different ways of construing the past was always there, but only relatively few studies made these nonhistoricist forms of history making the central focus of attention (Feeley-Harnik 1978; Rosaldo 1980; Sahlins 1981, 1985; Price 1983; Taussig 1984; Lederman 1986; Comaroff \& Comaroff 1987; Valeri 1990; Faubion 1993, p. 43). This area remained uncoordinated, with no distilled methodology or comparative synthesis and certainly no orientating label. These types of studies fall into the domain of historicity in anthropology, although by the early 1990s, it was not yet apparent how a phenomenological concept of historical relationality, a historicist concept of factuality, and anthropological accounts of diverse cultural forms of history making might add up.

Such an anthropological concept of historicity began to take shape in the wake of LéviStrauss's distinction between "hot" and "cold" societies (Lévi-Strauss 1966, 1983; Charbonnier 1969; Gell 1992, p. 23; Harkin 2009; Hartog 2015). All societies, Lévi-Strauss maintained, have historicity in the historians' sense of past factuality, but they also have different cultural frameworks for perceiving and representing the past. Through complexes of myth and ritual, some societies seek to annul the effects of time, whereas other societies 
embrace change or progress as foundational assumptions (Lévi-Strauss 1966, p. 234). Many understood this contrast between cold and hot societies as a typical Lévi-Straussian structural polarization, but it was more a spur to recognize the plethora of possible cultural interpretations of past events. The relationship of a society to its past could be any temperature. From this realization it was but a small step to Sahlins's (1981) historically detailed studies of how myth modulated eventuation in the Pacific, resulting in the memorable aphorism: "Different cultures, different historicities" (Sahlins 1985, p. x). This quote put the term historicity into circulation, while leaving it evocatively underdefined. The content of his Islands of History (Sahlins 1985), however, left no doubt that historicity was a shorthand for the cultural ordering of history, an analytic approach that Sahlins elaborated in subsequent works, issuing in the new gnomic phrase, "No history without culture" (2004, p. 292).

These developments rendered history "indefinite" (Faubion 1993, p. 44). A wedge had now been driven between historicity as verifiable factuality and historicity as a cultural perception of the past, thereby producing a minefield of potential misunderstanding between anthropologists on the one hand and historians and the general public on the other. OhnukiTierney (1990b) took historicity to refer to "the culturally patterned way or ways of experiencing and understanding history" (p. 4) and considered it to be synonymous with historical consciousness, although historicity had the advantage of not implying that these processes occurred consciously. She identified four features of historicity: $(a)$ their selectivity in the events recognized; (b) their plurality within a society; (c) the interdependence of past and present through metaphor and metonymy (i.e., the present is sometimes likened to the past and sometimes engineered to make the past tangible); and ( $d$ ) the subjective bias of those representing the past (Ohnuki-Tierney 1990b, p. 20). Although partially overlapping, very general, and incomplete, this was a first stab at specifying historicity as an anthropological analytic. Handelman \& Shamgar-Handelman (1990) illustrated this historicity through a study of Israel's adoption of the menorah (sevenbranched lampstand) as the national emblem in 1948. The new emblematic menorah explicitly referenced the menorah carved on the triumphal Arch of Titus in Rome, where it was carried as a spoil of war after the destruction of the Second Temple in $70 \mathrm{CE}$. The operation of a Jewish historicity working with spatial and temporal principles of sacred 
space (Canaan, Israel, Zion), exile (destruction, diaspora), and return (aliyah, redemption) elevated this design above all others---an example of cultural logic at work over the millennia in the making of Jewish history. The selection of the menorah was one more resonant expression of this history. In 1952, Israel's coordinator of the national committee on symbols described the menorah emblem as a "symbol of the past, the present, and the vision of a future of total perfection" (Handelman \& Shamgar-Handelman 1990, (p. 226). This formulation adds to Ohnuki-Tierney's third point above: Historicity interweaves not only the present and the past, but also the future.

Deriving as it did from historicism, the historicity idea could imply an arrangement where the past is over and done with (res gestae) and historicity arises only in contemporary cultural constructions of this past (historia res gestarum). The example of the Israeli menorah already shows that it is historiae, or historicities, all the way down; whatever happens is constantly culturally mediated. Trouillot (1995) grasped this nettle by differentiating a historicity 1 (the construction of past factuality in the past) from a historicity 2 (narratives about the past formed in a present on the basis of historicity 1). Although this move seemed to polarize the two, his intention was to show how selections, and therefore silences, inform the historical record from top to bottom. The past is not neutrally or transparently deposited as may readily be seen in the sociopolitics of taphonomy after Hurricane Katrina (Dawdy 2006). Ultimately, Trouillot's numbers may be dispensed with and "historicity" considered as the manifold interdependencies between a present (always sensing the future) and the pasts it elects to consider. This definition of historicity seems capacious and dynamic, and the only difference between it and a normal understanding of "history" would be the recognition of the shifting sands on which accounts of the past are built. Most practicing historians share this recognition that accounts of the past, and therefore some "facts" of the past, are subject to change although they tend to put that thought aside while writing histories that will ideally stand the test of time.

Trouillot's tangle with historicity may point to a fatal flaw in the concept. Perhaps it sits too firmly within the Western academic paradigm of "historicism" (Burke 2002; White 2002), which holds, among other things, that the present succeeds the past and that anachronism is impermissible (Chakrabarty 2000, p. 248). As Palmié (2013b) points out, the premise that the past and present are separate arguably smuggles in one of those "North 
Atlantic Universals" that Trouillot (2002) elsewhere deconstructed. Cases where the past speaks in the present through spirit possession (Lambek 1998, 2002; Palmié 2013a) or in dreams (Stewart 2012) contravene, furthermore, the separation between subject and object, one of the preconditions of post-Enlightenment scholarly (scientific) research. Dreaming and spirit possession often do not reference tangible documentary evidence that would offer the chance to confirm a reconstructed past independently. Such examples cannot pass muster as historical representations in Western terms, and they furthermore short-circuit Trouillot's two historicities. They conform more to Faulkner's (1951) dictum: “The past is never dead. It's not even past."

The question then is whether historicity can be resignified as a cross-cultural analytic term that allows the study of all the diverse ways in which the past may be construed without importing Western assumptions about history - a difficult task granted that the term has "history" in its very name. To orientate anthropological and ethnographic research, anthropologists must follow a procedure recommended by Humpty Dumpty [Carroll 2015 (1871)] and make the word mean exactly what they choose it to mean. It would have to signify the full variety of possible cultural means of perceiving, understanding, and representing the past. Western historicism would be just one such form among others within the category. Aside from organizing an area of study, this move fosters critical awareness of the treatment of Western historicist "common sense" (Herzfeld 2015) as if it were a "universal unmarked" (Trouillot 2002, p. 855) by exposing its limits in contrast with other historicities. Assumptions such as the subject-object distinction, mechanistic causality, linearity, and dispassionate inquiry, among others, undergo denaturalization.

One might be tempted to cast the problem in ontological terms (Henare et al. 2007; Viveiros de Castro 2013, 2015). That approach is inspirational insofar as it takes seriously the gap between different sociocultural realities, and there could be few more basic coordinates of reality than the considerations of time, event, and factuality that comprise historicity. Yet the ontological approach supposes a radical incommensurability between coherent ontologies (Killick 2014, Graeber 2015), but such internal unity is not the case for historicities at this point in world history. People might entertain several different historicities in the course of a day or combine them into novel composites. In the citation above, Faulkner captures an aspect of reality in the American South that contradicts the 
progressive historicism of America, a historicity that one may also find in the South.

Historicities, as Ohnuki-Tierney remarked above, are plural in any given society, and there has been plenty of interchange between societies over time; they may hybridize and rehybridize in ever-reformulating cultural entities (Stewart 2011). Rather than approaching historicities as the discrete and unitary orientations of a society, ethnographers might find it more productive to study how people negotiate the tensions between discrepant historicities as, for example, in the choice between human evolution, Biblical creationism, or intelligent design as the explanation of human origins (Trautmann 1991; Coleman \& Carlin 2004; Butler 2010; Bielo 2015). Attending to the politics of historicity may be one way to see historicities with increased clarity.

\section{THE POLITICS OF HISTORICITY}

Johannes Fabian's profound work, Time and the Other (1983), critiqued anthropology's propensity to place the people it studies in less advanced time zones, thereby denying them coevalness. This hierarchical time perspective is consistent with Western historicism, which he likened to a "political cosmology" or "myth" (p. 152)—one arrived at, it should be added, by an uneven secularization of Christian time (Hamann 2016). The central concept of progress within this cosmology promises a succession of better futures that continually and incrementally save people from stagnation, rather than leaving them waiting for ultimate divine salvation. Evolutionism offered but one further version of this, and although after Boas, sociocultural anthropologists rejected an evolutionary approach to global societies, a progressive sense of time nonetheless remained inherent in anthropological thought (Fabian 1983, p. 146; Thomas 1996).

How coevalness can be achieved, however, remains unresolved. For Fabian, it obtains in the conditions of presence, dialogue, and intersubjectivity that are characteristic of the field research experience. He did not envisage a merger of "Times" (Fabian 2014, p. 205) that would bring other historicities into the "temporal fortress" (Fabian 1983, p. 35) of the West. Erasing or subordinating their particularity would not be a solution. Certainly there is no generic Other, but many particular constructions of time such as Tibetan Buddhist reincarnation (da Col 2007), Jewish messianism (Kravel-Tovi \& Bilu 2008, Dein 2010), or 
Mapuche shamanic temporality (Bacigalupo 2014, 2016), each of which gives rise to different historicities. Rather than searching for a least common denominator, or forging a composite pidgin temporality, coevalness might involve reciprocal recognition of the multiple temporalities present within every society and the common human predicament of alternating between these various temporalities in the course of daily life (Bloch 1998, Birth 2008, Hamilakis \& Theou 2013).

Historians in the field of global history (Rüsen 2002, 2007; Duara et al. 2014) have entered this territory by inquiring into non-Western historical practice, although they have done so mostly as an exercise in comparative historiography following the Western assumption that history was a recognizable genre of writing. Granted the particularity of Western historical consciousness - the awareness (identified above by Fabian) that the past is separate from and superseded by the present ${ }^{1}$ - historians debated whether it could be said to exist in places such as China or India. Specialists on India have considered closely whether Indian history could be conveyed in poetry or in narratives of heroes and gods, the sorts of genres conventionally marked off from history as legend or myth (Pollock 2007, Rao et al. 2007, Das \& Randeria 2014). In postcolonial studies, writers have asked whether Indian forms of knowing the past such as the Puranas should be considered "alternative histories" or "alternatives to history" (Nandy 1995, p. 53). This is a tricky question and the answer, in my view, is that they must be seen as both: i.e., as performing a similar task to Western history insofar as they represent the past, yet also as substantially different in form and precept from Western history. For it to work analytically in anthropology, "history" cannot be taken as the singular set of assumptions deriving from Western historicism, for if this is done, one will measure only how similar other societies are to Western standards, which themselves may be parochial (Chakrabarty 2000). For history to be deployed in cross-cultural studies the idea needs to be widened to include the various methods people have for perceiving and relating to the past and the genres they have for representing it (Papailias 2005). Following on from this observation no one could be said to lack historical

\footnotetext{
${ }^{1}$ The modern attitude toward time viewed the present and future as ideally always new, hence the term Neuzeit (new time) coined in German as the term for modernity (Koselleck 2004). The consistency with capitalism (e.g. ideas of investment and economic growth) is plain to see.
} 
consciousness because this term would no longer imply that specific frame of thought constitutive of modernity, but rather whatever particular assemblage of ideas and information a given people entertain about the past (van Heekeren 2007). These changes in conceptualization place Western history within a field of comparison, but that does not necessarily alter its authority as the dominant historicity in many powerful countries. People such as the Mashpee generally need to master that idiom if they want to succeed in court, although there are exceptions (Glavin 1998).

According to the precepts of historicism, the world constantly changes, and the future, while assumed to be an improvement on the present, is essentially unpredictable. Historicism itself will thus likely change form in the future, and one of the factors driving that change may be the degree of interchange with other societies and cultures through globalization, migration, and travel. Until now, however, alternative historicities have not had much success in entering the West's temporal fortress, although occasionally they do get smuggled in like contraband (Nandy 1995, p. 53). Chakrabarty $(1998,2000)$ has called attention to the immigration procedures for admitting non-Western historicities into professional history. If the Santal (a tribal group in India) say that god commanded them to act, this must be converted into a statement such as "the people believed that their god spoke to them." Yet, as Chakrabarty also points out, Westerners, too, have numinous experiences where linear time gets out of joint, gods direct a person, or ghosts from the past appear with profound effects on one's life. When one takes account of the burgeoning popularity of historical fiction, film, and video games set in past periods (de Groot 2009), not to mention historical reenactments and living museums (Handler \& Saxton 1988, Handler \& Gable 1997), then it becomes clear that the average denizen of the West is happily participating in many different relationships with the past. Acknowledging this multiplicity of historicities inside Western societies illustrates what is entailed in establishing coevalness — in the sense considered above (Birth 2008) — with the nonhistoricist practices of those outside the West. For proponents of the ontological turn (Holbraad 2012, p. 237; Viveiros de Castro 2013), such encounters with radically different historicities may, through recursion, catalyze novel ways of thinking about these matters. The concept of history in the heartland might change. 


\section{ETHNOGRAPHIES OF HISTORICITY}

Historians and anthropologists are at cross-purposes on the question of truth. For the former, the whole point is to make true statements about the past, and this truth rests on verification in relation to evidence. Anthropologists may also operate in that mode, but an important goal is to capture the truth of how a particular people see the world. Historians work with a correspondence theory of truth, whereas anthropologists often work with a coherence theory that establishes the social and cultural contexts in which groups accept statements as credible. Their ethnographic accounts capture how societies understand and represent the past.

Such an approach parallels the philosophy of history - a field associated with names such as Reinhart Koselleck, Hayden White, and Paul Ricoeur-in devoting attention to the principles and cultural influences underlying the production of histories. In the field of history, there is a division of labor between historians who produce accounts of the past and philosophers of history who analyze and theorize what is involved in that task. In the ethnography of historicity, which lies within a larger anthropology of history (Palmié \& Stewart 2016), historical and ethnographic data, analysis, and theorization merge (Hughes \& Trautmann 1995; Lambek 2002, 2016; Hirsch \& Stewart 2005b; Hodges 2007; Stewart 2012; Bacigalupo 2016). The ethnography of historicity, furthermore, makes no preliminary assumptions about the form that histories might take. Historians' debates over whether a poem or a hymn might qualify as history appear reserved next to anthropologists' willingness to consider media such as treasure tales (Stewart 2003, Rose 2009), dance (Harris 2000, McCall 2000, Wulff 2007), fireworks (Sutton 1998), or spirit possession (Makris 1996, Larsen 1998, Lambek 2002, Palmié 2013a) as vehicles of historical consciousness. Anthropological analyses of historicity attend to the senses of time (temporality) that condition actors as individuals and members of society; the techniques and materials people resort to in learning about and representing the past; the specific principles that guide understanding of past action; and the context of any given historicity in relation to alternative historicities with differential authority. I turn to consider each of these in more detail below. 


\section{Time/Temporalities}

Hartog (2015, p. xv) has used the expression "regimes of historicity" to denote the various combinations of past, present, and future orientation, which form the prism through which a society views its "historicity" (in the historians' sense of actual eventuation). Some societies might place enormous emphasis on the past, whereas our own society, in Hartog's analysis, embraces a presentism that scants the past and the future. There is a small step between temporalities, which may be inchoate orientations, and historicities, which build on that temporality by adding experiences and cultural models, and then another, further step to the production of histories involving characters, events, and morality-infused emplotment. ${ }^{2}$ As an example, the apprehension felt by villagers on the Greek island of Naxos steadily increased as they watched the state appropriate their mining business (Stewart 2012). This existential crisis (temporality) spilled over into nocturnal dreams that pictured a prosperous future if the villagers could find certain icons and treasures buried in the ground. These objects offered history-laden alternatives to the heavy stones they normally mined, and stories began to circulate about who had hidden them. The past owners were said to have suffered persecution just like the villagers themselves. These historical accounts, including names and dates, completed the passage from temporality to historicization (Stewart 2012). A Christianity-imbued historicity in the middle of this circuit converted the stirrings of existential temporality (anxiety, hope) into the terms of a cosmology that envisaged ultimate salvation (historicity) with divine and miraculous interventions along the way, where saints and historical predecessors (history) could reappear in time and speak to people in dreams and visions as if present (cf. Rey 2017).

The Tibetan tradition of treasures ( ter $\mathrm{ma}$ ) formally resembles that of Naxos insofar as sacred texts are revealed through dreams, but it is mobilized by a different historicity. These textual treasures are attributed to the eighth-century culture hero Padmasambhava, who brought Tantric Buddhism to Tibet (Gyatso 1986). Those discovering such treasures

\footnotetext{
${ }^{2}$ This distinction draws on Heidegger's [1996 (1926)] differentiation between temporality and historicity in a chapter bearing that title in Being and Time: "How history can become a possible object for historiography can be gathered only from the kind of being of what is historical, from historicity and its rootedness in temporality" (p. 344).
} 
(tertons) — which have been found continuously since the tenth century - are considered reincarnations of historical disciples in whose minds Padmasambhava ensconced them more than 1,000 years ago. Treasure discovery thus enters the Tibetans into a temporal experience right on the border between temporality and historicity, ${ }^{3}$ where the golden age of Padmasambhava suddenly comes to life in the present via mental texts and material texts (sometimes inscribed stones) that have not been abraded by continuous physical existence (Gayley 2007). This encounter produces an unmediated experience of the past in the present. Such a historicity takes orientation from a cosmology of reincarnation that establishes a particular relationship to time. Western historicism, in contrast, derives its ideas of linearity and irreversibility from the cosmology of classical physics, although, as noted above, in daily life people do entertain multiple historicities, themselves possibly grounded in alternative temporalities. Gupta (1994) points out that, far from being polar opposites, the East and the West actually share many of the same ideas; it's just that whereas people are reincarnated in Tibet or India, in America it is commodities that return in periodic faddish revivals and relaunches.

\section{Materials, Methods, Performance}

Histories can be related in sculpture, such as the Marathon monument erected at Delphi after the Persian Wars, or painted, as at the Stoa in the Athenian agora or in the narrow confines of funerary shrines in Han-period China. As Tanner (2017) points out, the ancient Greeks positioned historicizing artworks where a large public could assemble to contemplate the analogies between themselves, their forbears, and the gods. The Chinese funerary paintings, by contrast, occupied a tight space such that no more than one viewer at a time could see the depiction of the past, perhaps kneeling as if in obeisance. Chinese viewers of the third century CE contemplated these funerary frescoes conditioned by a set of ideas about mirrors and divination that disposed them to see critically, beneath the surface of the past, into the inner workings of politics and corruption in order to better understand the present. Greek history in visual form encouraged expansive grandiosity, whereas

\footnotetext{
${ }^{3}$ This area of temporality on the border with historicity has been an area of growing research interest (Hodges 2008, 2010; Knight \& Stewart 2016).
} 
Chinese historicizing art produced critical introspection (Tanner 2017). These cases reveal the historicities at work in conditioning particular types of historical knowledge, a fruitful area for further research in the nexus between anthropology, art history, and archaeology.

Archaeologists have, like anthropologists, ventured beyond the task of providing history according to Western standards to study how people in the present and the past—who are/were not conditioned by historicism - might interpret objects and artifacts found in their environment (Gazin-Schwartz \& Holtorf 1999, Hamann 2002, Mayor 2005, Hamilakis 2008, Mortensen \& Hollowell 2009, Rozental 2016 ${ }^{4}$ ). In Anglo-Saxon Britain, for example, flint arrowheads found in the landscape were called "elf-shot" and attributed to the malign activity of elves.

Studies of spirit possession and shamanism, such as those offered by Lambek (2002) for Madagascar or Buyandelger (2013) for Mongolia, illuminate the rituals performed to learn about the past and the role of the experts who conduct them. Other performances of history include dance theater, singing, and plays (Hermann 2005, Hoëm 2005). In Bosnia, the deaths of so many people during the recent war have given new overtones to occasional prayers for the martyrs. These prayers have become more generally and pervasively chronotopic, producing a sense of immersion in the past (Henig 2017). The performative ritual technique of prayer affectively connects the recent dead with earlier martyrs from Ottoman times in a topological history (Tambar 2011, p. 486, Argenti 2017).

\section{Principles}

Many different principles inhere in the performances and representations of histories, and it is worth indicating some of them here to show the potential for further and deeper analyses. In the case of Bosnian prayer, affective connection would be one such principle - and one might contrast this with the principles of dispassionate presentation according to plausible cause and effect in professional historiography. The development of affect theory (Stewart 2007, Navaro-Yashin 2012) within anthropology encourages the conceptualization of the

\footnotetext{
${ }^{4}$ Rozental and Lerner have made a documentary film, The Absent Stone (http://www.lapiedraausente.com), about the removal of a large sculpture of Tlaloc from the village of San Miguel Coatlinchan for placement in front of the National Museum of Anthropology in Mexico City.
} 
diachronic circulation of feelings and meanings among subjects and objects, human and nonhuman. A growing interest in what Derrida termed "hauntology" has yielded studies of encounters with the ghosts of Native American spirits as a feature of American historicity (Boyd \& Thrush 2011), which may be compared with haunting by the past in China (Mueggler 2001) and Vietnam (Kwon 2008). The sensing of past events in landscapes (Harrison 2004), cityscapes (Glass 2016), or objects (Bryant 2014) can also activate historical consciousness. Feelings of hunger and apprehension during the current economic crisis have incited contemporary Greeks to think back to the famine endured 70 years earlier during the World War II German occupation in what Knight (2015) labels "cultural proximity" - a historical intimacy established by affective connection to a past. This supports Lévi-Strauss's (1966, p. 257) point that history is not ultimately structured by chronology — much though many believe it to be - but rather by myth or affective investment.

Bakhtin's idea of the chronotope, a literary device that creates historical settings or envelopes (Silverstein 2005, French 2012), can be seen as another principle for establishing relations with the past. In ordinary conversation and storytelling, the place-in-time might be set by verbal tense and description, but there can be many parallel and equally effective cues (Wirtz 2016). In their study of reunions of former residents of an inner-city neighborhood in Easton, Pennsylvania, known as Syrian Town, which was torn down for urban renewal in 1965, Eisenstein \& Smith (2016) show how the mention of place and personal names evoke the pre-1965 time-space. Through conversation, people collaboratively enter the chronotope and begin to use outmoded terms such as "the cat's meow" or "white slavery" (i.e., prostitution). The concept of chronotope implies the existence of multiple chronotopes that people might switch between in a "heterochronotopy" (K. Wirtz, personal communication), paralleling Bakhtin's idea of heteroglossia. People cite other voices, but they also evoke other times and, as shown by the Easton case and Bosnian prayer, they sometimes enter into these times. Spirit possession rituals can index chronotopes through the language spoken by different possessing spiritsFrench, for example, to indicate the colonial period in Madagascar (Lambek 2002) or a register known as Bozal to evoke the creolizing phase of early slavery in Cuba (Wirtz 2007). Without question, these chronotopes also induce affective responses such as 
nostalgia for the former inhabitants of Syrian Town or grief for the Bosnians entering the chronotope of mid-1990 Srebrenica.

\section{Politics}

The earlier discussion of coevalness has already opened the political dimension of historicities, so this section will be comparatively brief. In some communities such as the Inuit of Nunavut (Csonka 2005) or on the island of Tokelau (Hoëm 2005), the elders were the voice of authority regarding the past. In Western societies, the truth of the past is democratically ascertained in a public sphere of critique that tests accounts and constantly revises them. Competition between these accounts takes place within a single historicity, and contestations by holocaust deniers such as David Irving may be settled in court (Guttenplan 2002). Such conflicts over the past are always of interest, and they involve historicity in the historians' sense, but they do not necessarily activate the anthropological sense of the term.

Collisions between markedly different historicities such as between the British and Polynesians (Sahlins 1985) or between Orthodox Christian and Enlightenment historicities in Greece (Stewart 2012, p. 58) open the internal principles of historicities to view and bring their boundaries into focus. Yet multiple historicities may accumulate in any given society and, as seen in the case of prayer in Bosnia, historicities may also find new media as circumstances demand and as alternatives present themselves. With increased contact with Western historiography, one imagines that the preeminent authority of the elders in Nunavut to pronounce on the past will undergo marginalization, and Hoëm's (2005) account precisely concerns the competing forms of historicity that threaten the role of the elders on Tokelau.

\section{CONCLUSION}

Much of what has been considered above as historicity may well fall within memory studies, a field that has expanded considerably in the past few decades. Indeed, both historicity and memory draw attention to the social molding of perceptions of the past and the political contests between competing versions of the past. Furthermore, affect clearly stimulates and results from memories and historicities alike, and both may take shape in 
nonconscious or semiconscious states, across a variety of media. Like memory studies, the study of historicity opens critical perspectives on standard history. Not all memories or historicities may be validated as standard Western histories. Most memories, however, can probably be countenanced as historicities; indeed memory would be another principle of historicity. On the other hand, not all historicities would come into the purview of memory because they embrace deeper time spans where the personal storage and retrieval of experience does not arise as a possibility. The statue of Tlaloc in San Miguel Coatlinchan or the buried icons on Naxos incite historicizations rather than memories. One may remember the French Revolution, but only metaphorically, and overextending the memory concept in such cases is problematic (Berliner 2005). The historicity idea calls attention to processes of relating to the past that proceed from abduction (in Peirce's sense) rather than recollection, postulation rather than retrieval, discovery rather than recovery. In these respects, it is more compatible with Western historicism, to which it identifies alternatives, without reducing these forms to Western history or excluding them altogether as completely different types of knowledge.

A number of disciplines including history itself [postcolonial, world history, people's history (Samuel 1994)], ethnohistory (Nabokov 2002), archaeology (indigenous archaeology), museum studies (Tapsell 2003, Lonetree 2012), theorists of affect, and psychoanalysis and ghostly haunting (Gordillo 2004, 2009; Gordon 2008) have all converged on the need to understand alternative historicities. Considerations of the relevant methodologies for ethnographic study (Kilroy-Marac 2014, Glass 2016) as well as detailed ethnographies are appearing (Knight 2015; Bacigalupo 2016; Eisenstein \& Smith 2016). In addition, over the past two decades there have been various attempts to survey the idea of historicity and to summarize the contribution this concept can make to research (Trouillot 1995, Lenclud 1997, Hirsch \& Stewart 2005a, Detienne 2008, Delacroix et al. 2009, Ballard 2014, Hartog 2015, Hodges 2015). There have been collections of ethnographies of historicity (Whitehead 2003, Hirsch \& Stewart 2005b, Fausto \& Heckenberger 2007) and the development of parallel concepts such as "historical poiesis" (Lambek 1998), "historical consciousness" (Seixas 2004), and "historia" (Wallace 2005).

Despite these many contributions, the sense of historicity remains somewhat unclear because it is overdetermined by the three strands of thought considered through the course 
of this article: historical factuality, cultural perspectives on the past, and a circular hermeneutic relation between past and present. Add to this the fact that historicity depends closely on the concept of temporality, which itself may be understood as either a cultural relationship with time or an internal phenomenological sense of time where the past, present, and future may take various configurations (Hodges 2008). Thus contributors to this area sometimes talk past one another, but, far from sinking historicity in confusion, this conjuncture has somehow kept the historicity concept vital. The internal tensions have been productive. The least well-integrated strand has been the phenomenological dimension, yet it might be the most important for future research because it allows historicity to be situated outside of the linear expectations of historicism. This move grounds an approach that can consider a greater variety of relationships to the past as performing tasks similar to that of Western history.

\section{ACKNOWLEDGMENTS}

Multiple conversations with my long-standing collaborators Eric Hirsch and Stephan Palmié have shaped my thinking on historicity. I am grateful to them.

\section{LITERATURE CITED}

Argenti, N. 2017. Special Issue: Post-Ottoman Topologies. Soc. Anal. 61(1)

Bacigalupo AM. 2014. The potency of indigenous "Bibles" and biographies: Mapuche shamanic literacy and historical consciousness. Am. Ethnol. 41(4):648--63

Bacigalupo AM. 2016. Thunder Shaman: Making History with Mapuche Spirits in Chile and Patagonia. Austin: Univ. Tex. Press

Ballard C. 2014. Oceanic historicities. Contemp. Pac. 26(1):96--124

Berliner D. 2005 The abuses of memory: reflections on the memory boom in anthropology. Anthropol. Q. 78(1):197--211

Bielo J. 2015. Literally creative: intertextual gaps and artistic agency. In Scripturalizing the Human: The Written as Political, ed. V Wimbush, pp. 20--33. New York: Routledge Bloch M. 1998. Time, narratives and the multiplicity of representations of the past. In How We Think They Think: Anthropological Approaches to Cognition, Memory and Literacy, pp. 100-13. Boulder, CO: Westview 
Birth K. 2008. The creation of coevalness and the danger of homochronism. JRAI 14(1):3--20

Boyd C, Thrush C, eds. 2011. Phantom Past, Indigenous Presence: Native Ghosts in North American Culture and History. Lincoln: Univ. Neb. Press

Bryant R. 2014. History's remainders: belonging, temporality, and unfinished pasts. Am. Ethnol. 41(4):681--97

Burke P. 2002. Western historical thinking in a global perspective—10 theses. See Rüsen 2002, pp. $15--30$

Butler E. 2010. God is in the data: epistemologies of knowledge at the Creation Museum. Ethnos 75(3):229--51

Buyandelger M. 2013. Tragic Spirits: Shamanism, Memory, and Gender in Contemporary Mongolia. Chicago: Univ. Chicago Press

Carroll L. 2015 (1871). Through the Looking-Glass, and What Alice Found There. Proj. Gutenberg. Millenn. Fulcrum Ed. 1.7. http://www.gutenberg.org/ebooks/12

Chakrabarty D. 1998. Minority histories, subaltern pasts. Postcolon. Stud. 1(1):15--29

Chakrabarty D. 2000. Provincializing Europe: Postcolonial Thought and Historical Difference. Princeton, NJ: Princeton Univ. Press

Charbonnier G, ed. 1969. Conversations with Claude Lévi-Strauss, transl. J Weightman, D Weightman. London: Jonathan Cape

Clifford J. 1988. Identity in Mashpee. In The Predicament of Culture: Twentieth-Century Ethnography, Literature, and Art, pp. 277--346. Cambridge, MA: Harvard Univ. Press

Coleman S, Carlin L. 2004. The cultures of creationism: shifting boundaries of belief, knowledge, and nationhood. In The Cultures of Creationism: Anti-Evolutionism in EnglishSpeaking Countries, ed. S Coleman, L Carlin, pp. 1--28. London: Ashgate

Comaroff J, Comaroff JL. 1987. The madman and the migrant: work and labor in the historical consciousness of a South African people. Am. Ethnol. 14(2):191--209

Csonka Y. 2005. Changing Inuit historicities in West Greenland and Nunavut. Hist. Anthropol. 16(3):321--34

Da Col G. 2007. The view from somewhen: events, bodies and the perspective of fortune around Khawa Karpo, a Tibetan sacred mountain in Yunnan Province. Inner Asia 9(2):215--35

Das V, Randeria S. 2014. Democratic strivings, social sciences, and public debates: the case of India. Am. Anthropol. 116(1):160--65 
Dawdy SL. 2006. The taphonomy of disaster and the (re) formation of New Orleans. Am. Anthropol. 108(4):719--30

De Groot J. 2009. Consuming History: Historians and Heritage in Contemporary Popular Culture. London: Routledge

Dein S. 2010. A messiah from the dead: cultural performance in Lubavitcher messianism. Soc. Compass 57(4):537--54

Delacroix C, Dosse C, Garcia F, eds. 2009. Historicités. Paris: Éd. Découverte

Detienne M. 2008. Comparing the Incomparable, transl. J Lloyd. Stanford, CA: Stanford Univ. Press

Duara P, Murthy V, Sartori A, eds. 2014. A Companion to Global Historical Thought. Chichester, UK: Wiley Blackwell

Eisenstein A, Smith A. 2016. Rebuilding Shattered Worlds: Creating Community by Voicing the Past. Lincoln: Univ. Neb. Press

Evans-Pritchard EE. 1961. Anthropology and history. In Essays in Social Anthropology, pp. 46-65. London: Faber

Fabian J. 1983. Time and the Other: How Anthropology Makes Its Object. New York: Columbia Univ. Press

Fabian J. 2014. Ethnography and intersubjectivity: loose ends. HAU 4(1):199--209

Faubion J. 1993. History in anthropology. Annu. Rev. Anthropol. 22:35--54

Faulkner W. 1951. Requiem for a Nun. New York: Random House

Fausto C, Heckenberger M, eds. 2007. Time and Memory in Indigenous Amazonia: Anthropological Perspectives. Gainesville: Univ. Press Fla.

Feeley-Harnik G. 1978. Divine kingship and the meaning of history among the Sakalava of Madagascar. Man 13(3):402--17

French B. 2012. The semiotics of collective memories. Annu. Rev. Anthropol. 41:337--53

Gadamer H-G. 1994. Truth and Method, transl. J Weinsheimer, D Marshall. New York: Continuum. 2nd revis. ed.

Gayley H. 2007. Ontology of the past and its materialization in Tibetan treasures. In The Invention of Sacred Tradition, ed. J Lewis, O Hammer, pp. 213--40. Cambridge, UK: Cambridge Univ. Press

Gazin-Schwartz A, Holtorf CJ, eds. 1999. Archaeology and Folklore. London: Routledge 
Gell A. 1992. The Anthropology of Time. Oxford, UK: Berg

Glass PG. 2016. Using history to explain the present: the past as born and performed. Ethnography 17(1):92-110

Glavin T. 1998. A Death Feast in Dimlamahid. Vancouver: New Star Books

Gordillo G. 2004. Landscapes of Devils: Tensions of Place and Memory in the Argentinean Chaco. Durham, NC: Duke Univ. Press

Gordillo G. 2009. Places that frighten: residues of wealth and violence on the Argentine Chaco frontier. Anthropologica 51:343--51

Gordon AF. 2008. Ghostly Matters: Haunting and the Sociological Imagination. Minneapolis: Univ. Minn. Press

Graeber D. 2015. Radical alterity is just another was of saying "reality." HAU 5(2):1--41

Gupta A. 1994. The reincarnation of souls and the rebirth of commodities: representations of time in "East" and "West." In Remapping Memory: The Politics of TimeSpace, ed. J Boyarin, pp. 161--84. Minneapolis: Univ. Minn. Press

Guttenplan DD. 2002. The Holocaust on Trial. New York: Norton

Gyatso J. 1986. Signs, memory and history: a tantric Buddhist theory of scriptual transmission. $J$. Int. Assoc. Buddh. Stud. 9(2):7--35

Hamann B. 2002. The social life of pre-sunrise things: indigenous Mesoamerican archaeology. Curr. Anthropol. 43(3):351--82

Hamann B. 2016. How to chronologize with a hammer, or, the myth of homogenous, empty time. $H A U 6(1)$

Hamilakis Y. 2008. Decolonizing Greek archaeology: indigenous archaeologies, modernist archaeology, and the post-colonial critique. In A Singular Antiquity: Antiquity, Archaeology and Greekness in Twentieth Century Greece, ed. D Plantzos, D Damaskos, pp. 273--84. Athens: Benaki Mus.

Hamilakis Y, Theou E. 2013. Enacted multi-temporality: the archaeological site as a shared, performative space. In Reclaiming Archaeology: Beyond the Tropes of Modernity, ed. A Gonzalez-Ruibalm, pp. 181--94. London: Routledge

Handelman D, Shamgar-Handelman L. 1990. Shaping time: the choice of the national emblem of Israel. See Ohnuki-Tierney 1990a, pp. 193--226 
Handler R, Gable E. 1997. The New History in an Old Museum: Creating the Past at Colonial Williamsburg. Durham, NC: Duke Univ. Press

Handler R, Saxton W. 1988. Dyssimulation: reflexivity, narrative, and the quest for authenticity in "living history." Cult. Anthropol. 3(3):242--60

Harkin M. 2009. Structuralism and history. In The Cambridge Companion to Lévi-Strauss, ed. B Wiseman, pp. 39--58. Cambridge, UK: Cambridge Univ. Press

Harkin M. 2010. Ethnohistory's ethnohistory. Soc. Sci. Hist. 34(2):113--28

Harris M. 2000. Aztecs, Moors, and Christians: Festivals of Reconquest in Mexico and Spain. Austin: Univ. Tex. Press

Harrison S. 2004. Forgetful and memorious landscapes. Soc. Anthropol. 12(2):135--51

Hartog F. 2015 (2003). Regimes of Historicity: Presentism and Experiences of Time, transl. S Brown. New York: Columbia Univ. Press

Heidegger M. 1996 (1926). Being and Time, transl. J Stambaugh. Albany: State Univ. N. Y. Press

Henare A, Holbraad M, Wastell S. 2007. Introduction: Thinking through things. In Thinking Through Things: Theorizing Artefacts Ethnographically, pp. 1--31. London: Routledge

Henig D. 2017. Prayer as a history: of witnesses, martyrs, and plural pasts in postwar BosniaHerzegovina. Soc. Anal. 61(1)

Hermann E. 2005. Emotions and the relevance of the past: historicity and ethnicity among the Banabans of Fiji. Hist. Anthropol. 16(3):275--91

Herzfeld M. 2015. Common sense, anthropology of. In International Encyclopedia of the Social and Behavioural Sciences, Vol. 4, ed. JD Wright, pp. 258--62. Oxford, UK: Elsevier. 2nd ed.

Hirsch E, Stewart C. 2005a. Introduction: Ethnographies of historicity. Hist. Anthropol. $16(3): 261--74$

Hirsch E, Stewart C, eds. 2005b. Special Issue: Ethnographies of Historicity. Hist. Anthropol. $16(3)$

Hodges M. 2007. The Ethnography of Time: Living with History in Modern Rural France. Lewiston, NY: Edward Mellen Press

Hodges M. 2008. Rethinking time's arrow. Anthropol. Theory 8(4):399--429

Hodges M. 2010. The time of the interval: historicity, modernity, and epoch in rural France. Am. Ethnol. 37(1):115--31 
Hodges M. 2015. Reinventing "history"? Hist. Anthropol. 26(4):515--27

Hoëm I. 2005. Stealing the water of life: the historicity of contemporary social relationships. Hist. Anthropol. 16(3):293--305

Holbraad M. 2012. Truth in Motion: The Recursive Anthropology of Cuban Divination. Chicago: Univ. Chicago Press

Hughes DO, Trautmann TR. 1995. Time: Histories and Ethnologies. Ann Arbor: Univ. Mich. Press

Iggers G. 1995. Historicism: the history and meaning of the term. J. Hist. Ideas 56(1):129--52

Killick E. 2014. Whose truth is it anyway? Anthropol. Cent. Issue 9. http://aotcpress.com/articles/truth/

Kilroy-Marac K. 2014. Speaking with revenants: haunting and the ethnographic enterprise. Ethnography 15(2):255--76

Knight D. 2015. History, Time, and Economic Crisis in Central Greece. New York: Palgrave

Knight DM, Stewart C, eds. 2016. Special Issue: Ethnographies of Austerity: Temporality, Crisis and Affect in Southern Europe. Hist. Anthropol. 27(1)

Koselleck R. 2004. Futures Past: On the Semantics of Historical Time, transl. K Tribe. New York: Columbia Univ. Press

Kravel-Tovi M, Bilu Y. 2008. The work of the present: constructing messianic temporality in the wake of failed prophecy among Chabad Hasidim. Am. Ethnol. 35(1):64--80

Krech S. 1991. The state of ethnohistory. Annu. Rev. Anthropol. 20:345--75

Kwon H. 2008. The Ghosts of War in Vietnam. Cambridge, UK: Cambridge Univ. Press

Lambek M. 1998. The Sakalava poiesis of history: realizing the past through spirit possession in Madagascar. Am. Ethnol. 25(2):106--27

Lambek M. 2002. The Weight of the Past: Living with History in Mahajanga, Madagascar. New York: Palgrave

Lambek M. 2016. On being present to history: historicity and brigand spirits in Madagascar. HAU 6(1)

Larsen K. 1998. Spirit possession as historical narrative. In Locality and Belonging, ed. N Lovell, pp. 125--46. London: Routledge

Lederman R. 1986. Changing times in Mendi: notes towards writing Highland New Guinea history. Ethnohistory 33(1):1--30 
Lenclud G. 1997. History and tradition. In Present Is Past: Some Uses of Tradition in Native Societies, ed. M Mauzé, pp. 43--64. Lanham, MD: Univ. Press Am.

Lévi-Strauss C. 1966. The Savage Mind. Chicago: Univ. Chicago Press

Lévi-Strauss C. 1983. Histoire et ethnologie. Ann. Écon. Soc. Civilis. 38(6):1217--31

Lonetree A. 2012. Decolonizing Museums: Representing Native America in National and Tribal Museums. Chapel Hill: Univ. N. C. Press

Makris GP. 1996. Slavery, possession and history: the construction of the self among slave descendants in the Sudan. Africa 66(2):159--82

Mayor A. 2005. Fossil Legends of the First Americans. Princeton, NJ: Princeton Univ. Press

McCall JC. 2000. Dancing Histories: Heuristic Ethnography with the Ohafia Igbo. Ann Arbor: Univ. Mich. Press

Mortensen L, Hollowell J, eds. 2009. Ethnographies and Archaeologies: Iterations of the Past. Gainesville: Univ. Fla. Press

Mueggler, E. 2001. The Age of Wild Ghosts: Memory, Violence and Place in Southwest China. Berkeley: Univ. Cal. Press.

Munn ND. 1990. Constructing regional worlds in experience: Kula exchange, witchcraft and Gawan local events. Man 25(1):1--17

Munn ND. 1992. The cultural anthropology of time: a critical essay. Annu. Rev. Anthropol. 21:93--123

Nabokov P. 2002. A Forest of Time: American Indian Ways of History. Cambridge, UK: Cambridge Univ. Press

Nandy A. 1995. History's forgotten doubles. Hist. \& Theory 34(2):44-66

Navaro-Yashin Y. 2012. The Make-Believe Space: Affective Geography in a Postwar Polity. Durham, NC: Duke Univ. Press

Ohnuki-Tierney E, ed. 1990a. Culture Through Time: Anthropological Approaches. Stanford, CA: Stanford Univ. Press

Ohnuki-Tierney E. 1990b. Introduction: The historicization of anthropology. See OhnukiTierney 1990a, pp. 1--25

Ortner S. 1984. Theory in anthropology since the sixties. Comp. Stud. Soc. Hist. 26(1):126--66

Palmié S. 2013a. Historicist knowledge and its conditions of impossibility. In The Social Life of Spirits, ed. RL Blanes, D Espirito Santo, pp. 218--39. Chicago: Univ. Chicago Press 
Palmié S. 2013b. The trouble with history. Small Axe 17:193--202

Palmié S, Stewart C, eds. 2016. Special Section: The Anthropology of History. HAU 6(1)

Papailias P. 2005. Genres of Recollection: Archival Poetics and Modern Greece. New York: Palgrave Macmillan

Pollock S. 2007. Pretextures of time. Hist. Theory 46(3):366--83

Price R. 1983. First-Time: The Historical Vision of an Afro-American People. Baltimore, MD: Johns Hopkins Univ. Press

Rao VN, Shulman D, Subrahmanyam S. 2007. A pragmatic response. Hist. Theory 46(3):409--27

Rey S. 2017. Between dreams and traces: memory, temporality, and the production of sainthood in Lesbos. Soc. Anal. 61(1)

Ricoeur P. 2004. Memory, History, Forgetting, transl. K Blamey, D Pellauer. Chicago: Univ. Chicago Press

Rosaldo R. 1980. Ilongot Headhunting, 1883--1974: A Study in Society and History. Stanford, CA: Stanford Univ. Press

Rose D. 2009. Telling treasure tales: commemoration and consciousness in Dominica. J. Am. Folk. 122(2):127--47

Rozental S. 2016. In the wake of patrimonio: reconstituting the fragments of history in San Miguel Coatlinchan. Anthropol. Q. 89(1):157--96

Rüsen J. 2002. Western Historical Thinking: An Intercultural Debate. New York: Berghahn Books

Rüsen J. 2007. Time and History: The Variety of Cultures. New York: Berghahn Books

Sahlins M. 1981. Historical Metaphors and Mythical Realities: Structure in the Early History of the Sandwich Islands Kingdom. Ann Arbor: Univ. Mich. Press

Sahlins M. 1985. Islands of History. Chicago: Univ. Chicago Press

Sahlins M. 1991. The return of the event, again: with reflections on the beginnings of the great Fijian war of 1843 to 1855 between the kingdoms of Bau and Rewa. In Clio in Oceania: Toward a Historical Anthropology, ed. A Biersack, pp. 37--99. Washington, DC: Smithson. Inst.

Sahlins M. 2004. Apologies to Thucydides: Understanding History as Culture and Vice Versa. Chicago: Univ. Chicago Press 
Samuel R. 1994. Theatres of Memory. Volume 1: Past and Present in Contemporary Culture. London: Verso

Seixas PC, ed. 2004. Theorizing Historical Consciousness. Toronto: Univ. Tor. Press

Silverstein M. 2005. Axes of evals: token versus type interdiscursivity. J. Linguist. Anthropol. $15(1): 6--22$

Stewart C. 2003. Dreams of treasure: temporality, historicization and the unconscious. Anthropol. Theory 3(4):481--500

Stewart C. 2011. Creolization, hybridity, syncretism, mixture. Port. Stud. 27(1):48--55

Stewart C. 2012. Dreaming and Historical Consciousness in Island Greece. Cambridge: Harvard University Press.

Stewart K. 2007. Ordinary Affects. Durham, NC: Duke Univ. Press

Strathern M. 2013 (1990). Artifacts of history: events and the interpretation of images. In Learning to See in Melanesia. Masterclass Ser. HAU, Append. I:157--78

Sutton D. 1998. Memories Cast in Stone: The Relevance of the Past in Everyday Life. Oxford, UK: Berg

Tambar K. 2011. Iterations of lament: anachronism and affect in a Shi'i Islamic revival in Turkey. Am. Ethnol. 38(3):484--500

Tanner J. 2017. Visual art and historical representation in ancient Greece and China. In Ancient Greece and China Compared: Cross-Cultural and Interdisciplinary Perspectives, ed. G Lloyd, J Zhao. Cambridge, UK: Cambridge Univ. Press

Tapsell P. 2003. Beyond the frame: an afterword. In Museums and Source Communities: A Routledge Reader, ed. L Peers, AK Brown, pp. 242--51. London: Routledge

Taussig M. 1984. History as sorcery. Representations 7:87--109

Thomas N. 1996. Out of Time: History and Evolution in Anthropological Discourse. Ann Arbor: Univ. Mich. Press. 2nd ed.

Trautmann T. 1991. The revolution in ethnological time. Man 27(2):379--97

Trouillot M-R. 1995. Silencing the Past: Power and the Production of History. Boston: Beacon Press

Trouillot M-R. 2002. North-Atlantic universals: analytical fictions, 1492--1945. South Atl. Q. 101(4):839--58 
Valeri V. 1990. Constitutive history: genealogy and narrative in the legitimation of Hawaiian kingship. See Ohnuki-Tierney 1990a, pp. 154--92

Van Heekeren D. 2007. The essence of Vula'a historical consciousness. Hist. Anthropol. $18(4): 405--26$

Viveiros de Castro E. 2013. The relative native. HAU 3(3):473--502

Viveiros de Castro E. 2015. Who is afraid of the ontological wolf? Some comments on an ongoing anthropological debate. Camb. J. Anthropol. 33(1):2--17

Wallace AFC. 2005. The consciousness of time. Anthropol. Conscious. 16(2):1--15

Wentzer TS. 2014. 'I have seen Königsberg burning': philosophical anthropology and the responsiveness of historical experience. Anthropol. Theory 14(1):27--48

White H. 2002. The Westernization of world history. See Rüsen 2002, pp. 111--18

Whitehead N, ed. 2003. Histories and Historicities in Amazonia. Lincoln: Univ. Neb. Press

Wirtz K. 2007. Enregistered memory and Afro-Cuban historicity in Santería's ritual speech. Lang. Comm. 27:245--57

Wirtz K. 2016. The living, the dead, and the immanent: dialogue across chronotopes. HAU 6(1)

Wulff H. 2007. Dancing at the Crossroads: Memory and Mobility in Ireland. New York: Berghahn 